\title{
Prinsip Free And Prior Informed Consent Terhadap Perlindungan Masyarakat Adat Atas Tanah Dalam Perspektif Hukum Hak Asasi Manusia Internasional
}

\author{
Ikbal \\ Bagian Hukum Internasional Fakultas Hukum Untad \\ Kampus Bumi TadulakoTondo Palu
}

\begin{abstract}
The true policy in protection of land indigenuos peoples in Indonesian can be done by implemented the "free and prior informed consent" in national and local regulation, as international human right law placing these principle as fundamental principle which internalized in all articles.
\end{abstract}

\section{PENDAHULUAN}

Landasan hukum pertanahan di Indonesia adalah Undang-Undang Pokok Agraria (UUPA) Nomor 5 tahun 1960 yang sekaligus mengakui eksistensi masyarakat adat, sebagaimana diatur dalam Pasal 3 sebagai berikut:

"...pelaksanaan hak ulayat dan hak-hak yang serupa itu dari masyarakat-masyarakat hukum adat, sepanjang menurut kenyataannya masih ada, harus sedemikian rupa sehingga sesuai dengan kepentingan nasional dan negara, yang berdasarkan atas persatuan bangsa serta tidak boleh bertentangan dengan undang-undang dan peraturan-peraturan lain yang lebih tinggi"

Mencermati ketentuan di atas, menurut Maria Rita Ruwiastuti, bahwa visi pembuat undang-undang tersebut jelas melatar belakangi corak dan arah politik hukum agraria mengenai status tanah-tanah hak ulayat dari masyarakat adat, sehingga dalam Pasal 3 undang-undang ini dirumuskan bahwa pelaksanaan hak ulayat harus sesuai dengan "kepentingan nasional dan negara", maksudnya adalah bahwa pelaksanaan hak-hak itu dibatasi oleh bekerjanya hak menguasai yang ada ditangan negara, dalam kasus-kasus tertentu pembatasan itu berarti peniadaan hak ulayat. ${ }^{1}$

Realitas produk hukum negara sebagaimana telah disebutkan di atas juga ditanggapi oleh Ibnu Elmi A.S. ${ }^{2}$ Menurutnya, produk hukum negara tersebut jelas menggambarkan adanya sifat mendua elit politik bangsa Indonesia yang masih terasa pada saat ini, dikarenakan modernisasi hukum dilangsungkan akan tetapi masih terpaku di bawah pesona hukum adat, mengakibatkan hukum nasional memberikan kesempatan pada masyarakat dan hukum adat untuk dikembangkan dalam konteks perundang-undangan, akan tetapi kesempatan tersebut belum sepenuh hati, dikarenakan kuatnya suatu anggapan bahwa hukum adat hanya memperlambat proses kemajuan bangsa. Apa yang

\footnotetext{
${ }^{1}$ Maria Rita Ruwiastuti, Sesat Pikir Politik Hukum Agraria, Insist Press, KPA dan Pustaka Pelajar, Yogyakarta, 2000, hlm. 115.

${ }^{2}$ Ibnu Elmi A.S. Pelu, et.al, Reaktualisasi Cita Hukum dalam Pembangunan, In-Trans, Malang, 2007, hlm. 148-149.
} 
telah disebutkan, dapat dilihat dari berbagai produk hukum pemerintah yang memberi ruang bagi pengakuan dan eksistensi masyarakat adat dan haknya dalam sistem hukum negara namun bersifat birokratik.

Sifat mendua para elit politik dalam mengakui hak masyarakat adat juga tedapat dalam UU No 41 tahun 1999 tentang Kehutanan, menegaskan kalaupun suatu masyarakat adat itu dinyatakan masih ada, kegiatan pengelolaan hutan dan pemanfaatan hasil hutan dilaksanakan di atas hutan negara bukan di atas hutan ulayatnya. Sebagaimana jelas dalam rumusan Pasal 1 bahwa "Hutan adat adalah hutan negara yang berada di wilayah masyarakat hukum adat".

Dasar konstitusional dari kebijakan hak ulayat di atas terletak pada Pasal 33 ayat (3) dari UndangUndang Dasar (UUD) 1945 dan dijabarkan lebih lanjut dalam Pasal 2 UUPA keduanya menyatakan bahwa semua tanah dan SDA di Indonesia dikuasai oleh negara. Menurut Rakhmad Syafa'at, hak menguasai negara pada dasarnya merupakan cerminan dari implementasi nilai, norma, dan konfigurasi hukum negara yang mengatur penguasaan dan pemafaatan tanah dan SDA, atau merupakan ekspresi dari idiologi yang memberi otoritas dan legitimasi kepada negara untuk menguasai dan memanfaatkan tanah dan SDA dalam wilayah kedaulatannya. ${ }^{3}$

Namun demikian, dalam kurun waktu lebih dari 3 dekade, pemerintah Orde Baru secara sadar telah memanipulasi makna hakiki dari konsep penguasaan dan pemanfaatan SDA seperti yang

3 Rakmad Syafa'at, et.al, Negara Masyarakat Adat dan Kearifan Lokal, Trans Publishing, Semarang, 2008, hlm. 31. dimaksud dalam Pasal 33 ayat (3) UUD 1945. Dalam hal ini setidaknya terdapat dua hal pokok:

1. Pemerintah Orde Baru memberi interpretasi sempit dan tunggal atas terminologi negara (state). Negara pada dasarnya terdiri atas pemerintah dan rakyat, tetapi selama ini pemerintah orde baru, negara semata-mata diartikan sebagai pemerintah saja, bukan sebagai rakyat dan pemerintah (government dominated resource management) bukan paradigma state based resource managemant seperti yang dimaksud oleh Pasal 33 ayat (3) UUD 1945.

2. Konsekuensinya, dalam praktek penyelenggaraan negara seperti di atas memposisikan rakyat menjadi tidak sejajar dengan kedudukan pemerintah, karena diciptakan relasi yang menempatkan rakyat subordinasi dan pemerintah sebagai superordinasi, atau rakyat diposisikan sebagai inferior dan pemerintah berada dalam kedudukan yang superior. ${ }^{4}$

Kecendrungan interpretsi seperti yang dijelaskan di atas, bukan tidak mungkin menimbulkan dampak terhadap masyarakat adat karena pada posisi yang demikian menurut Fokky Fuad akan muncul model pengelolaan SDA dengan hukum yang bersifat represif (represif law) yang mengekspresikan kekuasaan pemerintah kemudian mangabaikan dan menggusur keberadaan masyarakat adat. ${ }^{5}$ Pada model seperti

${ }^{4}$ Fokky Fuad, "Hak Masyarakat Hukum Adat dalam Pengelolaan Sumberdaya Tambang di Indonesia", Jurnal Hukum Ekonomi dan Tekhnologi Fakultas Hukum Universitas Alazhar Indonesia", No. 1 Maret 2006, hlm. 35.

${ }^{5}$ Beberapa bentuk instrumen hukum yang berkaitan dengan SDA dalam sistem hukum Indonesia sebagaimana dikemukakan oleh I 
itu posisi masyarakat adat untuk mempertahankan hak-hak atas tanah mereka berhadapan dengan pemerintah akan sangat lemah.

Model kebijakan seperti di atas, memungkinkan negara untuk memberikan hak-hak di atas hak tanah ulayat yang tidak atau belum diolah tanpa memberi persetujuan dari masyarakat adat yang terkait, dan tanpa harus memberi kewajiban hukum untuk membayar kompensasi yang memadai kepada masyarakat adat yang mempunyai hak ulayat atas tanah tersebut. Praktik ini muncul biasanya sehubungan dengan pemberian hak pengusahaan hutan kepada Hak Pengelolaan Hutan (HPH), penetapan hutan lindung, dan alokasi tanah bagi proyek transmigrasi. Implikasi dari model hukum yang bersifat represif tersebut menyebabkan masyarakat adat tergusur, terabaikan dan termarginalisasikan sebagai akibat dari kebijakan pembangunan. Dengan kata lain kebijakan dan sikap pemerintah dalam pembangunan menjadi sumber penyebab penghancuran secara sistematis terhadap integritas nilai-nilai ekonomi, sosial dan budaya

Nyoman Nurjaya, di antaranya adalah UUPA No. 5 tahun 1960, UU No. 11 tahun 1967 tentang Pertambangan, UU No. 11 tahun 1974 tentang Pengairan, UU No. 9 tahun 1985 tentang Perikanan dan UU No. 41 tahun 1999 tentang Kehutanan pada dasarnya memiliki berbagai kelemahankelemahan substansial. Di antara berbagai kelemahan tersebut salah satunya adalah tidak diakui dan dilindunginya HAM secara untuh, terutama hak masyarakat adat dan kemajemukan hukum dalam penguasaan dan pemanfaatan SDA. Lihat selengkapnya dalam I Nyoman Nujaya, Pengelolaan Sumber Daya Alam dalam Perspektif Antropologi Hukum, Prestasi Pustaka Publisher, Jakarta, 2008, hlm. 126-127. masyarakat adat yang sangat tergantung pada tanah mereka.

Persoalan-persoalan yang muncul dalam pemanfaatan SDA seperti diuaraikan di atas, menurut I Nyoman Nurjaya, sesungguhnya bersumber dari anutan paradigma pengelolaan SDA yang bercorak sentralistik, berpusat pada negara (state-based resource management), mengedepankan pendekatan sektoral, dan mengabaikan perlindungan HAM. Paradigma seperti ini selain tidak mengutamakan perlindungan serta keberlanjutan fungsi SDA, juga tidak secara untuh memberi ruang partisipasi masyarakat, serta mengabaikan hak-hak masyarakat adat atas penguasan SDA. Hal ini akan berimplikasi pada beberapa bidang kehidupan masyarakat adat. Dari segi ekonomi akan menghilangkan sumber-sumber ekonomi bagi kehidupan masyarakat adat (economic resources loss), dari segi sosial dan budaya secara nyata telah merusak sistem pengetahuan, tekhnologi, institusi, tradisi dan religi masyarakat adat (social cultural loss). ${ }^{6}$ Dengan semangat sentralistik itu pula, masyarakat terutama yang berdiam di wilayah yang akan dilakukan kegiatan pengelolaan SDA tidak pernah diberi informasi dan dimintakan persetujuan bagi rencana pemberian izin pengelolaan SDA. Hal ini mengabaikan satu prinsip penting dalam pengelolaan SDA yang dikenal sebagai Prior Informed Consent (PIC). ${ }^{7}$

Dampak dari kondisi di atas, jika tidak diselesaikan secara arif bukan tidak mungkin akan menimbulkan konflik dan resistensi dari masyarakat adat khususnya bagi mereka yang berada di daerah-daerah

\footnotetext{
${ }^{6}$ Ibid., hlm, 125.

${ }^{7}$ Ibid., hlm. 105.
} 
yang kaya akan sumberdaya alamnya. Munculnya gerakan separatis dan kasus-kasus kerusuhan di berbagai wilayah Indonesia dan diikuti tuntutan untuk merdeka lepas dari Negara Kesatuan Republik Indonesia (NKRI) adalah hal yang perlu diwaspadai jika eksistensi mereka tidak mendapatkan tempat yang layak di negeri ini. Sebagai contoh yang terjadi di Timika, antara masyarakat Amungme dan Kamoro dengan PT Freeport yang dibantu aparat keamanan setempat. Hasil penelitian PBB melalui lembaga penelitiannya the UN Research Institute for Social Development memperkirakan sekitar 50 peristiwa konflik mengenai etnik dan perkembangan sosial. Mayoritas pemicu konflik tersebut adalah berkaitan dengan kemiskinan ekonomi dan perebutan atas sumberdaya yang semakin langka dan sebenarnya digunakan untuk kehidupan mereka. ${ }^{8}$

Berangkat dari uraian latar belakang di atas, maka persoalan yang dikedepankan dalam tulisan ini adalah terkait dengan pencarian konsep kebijakan pengaturan yang tepat melalui hukum HAM internasional terhadap hak masyarakat adat atas tanah?

\section{Pembahasan}

\subsection{Prinsip Free and Prior Informed Consent dalam Hukum HAM Internasional}

Hakikat HAM dapat dipahami dari unsur-unsur yang terkandung dalam pengertiannya yakni HAM merupakan hak dasar yang dimiliki

${ }^{8}$ Sri Rahayu Oktoberina, "Hak Asasi Manusia dan Lingkungan Hidup dalam Hukum Internasional", Jurnal Keadilan, Vol. 2. No. 2, Tahun 2002, hlm. 37-45. oleh setiap manusia tanpa kecuali, hak itu diperoleh langsung dari Tuhan dan bersifat kodrati. Dengan demikian HAM dikatakan berasal dari Tuhan dan karenanya bersifat kodrati.

Konsep HAM yang bersumber dari kodrat manusia tersebut bersifat abstrak, maka untuk memahami HAM dikonkritkan dalam aturanaturan baik dalam aturan internasional maupun nasional sehingga menjadi sumber dan dasar HAM. Namun demikian, sumber yang dimaksud adalah dalam arti formil, bukan dalam arti materil, karena secara materil, HAM berasal dari kodrat manusia itu sendiri dan juga bersumber dari Tuhan. Dengan demikian HAM pada prinsipnya bukanlah pemberian seseorang ataupun pemberian negara hukum, namun semata-mata adalah karunia dari Allah SWT. ${ }^{9}$

Perlindungan HAM pada umumnya dan hak masyarakat adat atas tanah khususnya jika ditinjau dari teori HAM, terdapat tiga aspek keberadaan manusia yang harus dilindungi yaitu, integritas manusia, kebebasan dan kesetaraan. Dasar bagi terciptanya tiga aspek ini adalah penghormatan terhadap martabat setiap manusia. Dalam hal ini, negara ada dan dibentuk oleh manusia

\footnotetext{
${ }^{9}$ Sebagaimana dikatakan oleh Al-maududi, HAM bukanlah pemberian siapa-siapa tapi adalah pemberian Tuhan kepada seseorang sejak ia terlahir kedalam alam dunia. Sebab, kalau hak itu dianggap pemberian manusia, misalnya dari negara atau parlemen, ia dapat ditarik kembali dengan cara yang sama ketika hak itu diberikan. Karena hak-hak asasi itu datangnya dari Tuhan, maka tak satupun lembaga atau perorangan di dunia ini berhak mencabut atau membatalkannya. Dalam Ahmad Kosasih, HAM dalam Perspektif Islam: Menyingkap Persamaan Antara Islam dan Barat, Salembah Diniyah, Jakarta, 2003, hlm. xvii.
} 
semata-mata untuk menjamin perlindungan hak milik manusia yakni kehidupan, kebebasan, dan hak milik.

Hak kepemilikan $^{10}$ pada umumnya dan kepemilikan tanah masyarakat adat khususnya dapat dilihat dalam Pasal 17 UDHR sebagaimana disebutkan: ayat (1) "Everyone has the right to own property alone as well as in association with others' (Setiap orang berhak memiliki harta, baik sendiri maupun bersama-sama dengan orang lain), dan ayat (2) berbunyi "No one shall be arbitrarily deprived of his property" (Tidak seorang pun yang dapat dirampas hak miliknya secara semena-mena). Namun demikian, hak yang dilindungi dalam Pasal 17 UDHR tersebut tidak bersifat mutlak, dalam arti bahwa seseorang dapat diambil hak miliknya, asalkan sesuai dengan proses hukum yang adil dan fair (due process of law), tanpa diskriminasi dan dengan kompensasi yang adil. ${ }^{11}$

Hal di atas sejalan dengan salah satu ketentuan yang termuat

\footnotetext{
${ }^{10}$ Dalam kovenan ICCPR dan ICESCR tidak terdapat ketentuan khusus tentang hak kepemilikan seperti halnya yang diatur dalam UDHR. Namun secara tidak langsung hak tersebut mendapatkan perlindungan melalui ketentuan tentang non-diskriminasi yang berdiri sendiri. Ketentuan ini memberikan perlindungan terhadap diskriminasi dalam menikmati seluruh hakhak termasuk hak atas properti, meskipun hak atas properti tidak tercantum sebagai hak khusus dalam dua kovenan tersebut. Demikan pula halnya dalam ICERD juga menjamin hak atas properti dari perlakuan diskriminatif dalam segala bentuk termasuk hak untuk mewarisi, sebagaimana diatur dalam Pasal 5 (d) [v] dan [vi] ICERD

${ }^{11}$ Rafael Edi Bosko, Hak-Hak Masyarakat Adat dalam Konteks Pengelolaan Sumber Daya Alam, ELSAM, Jakarta, 2006, hlm 119.
}

dalam Pasal 10 UNDRIP sebagaimana disebutkan bahwa:

"Masyarakat adat tidak boleh dipindahkan secara paksa dari tanah atau wilayah mereka. Tidak boleh terjadi relokasi tanpa ada persetujuan atas informasi yang jelas terlebih dahulu kepada masyarakat adat dan setelah ada persetujuan dan dengan kompensasi yang adil dan jujur, dimana kalau ada kemungkinan, diberi pilihan untuk mereka kembali".

Ketentuan di atas memberikan dasar pijakan perlindungan masyarakat adat atas tanah tentang larangan tindakan semena-mena terhadap perampasan tanah masyarakat adat sebagaimana dimaksud dalam Pasal 17 ayat (1) dan (2) UDHR. Beberapa syarat yang harus dipenuhi dalam hal relokasi masyarakat adat, Pertama, pemindahan masyarakat adat hanya dapat dilakukan jika persetujuan bebas dan informasi yang jelas (free and prior informed consent) telah diadakan. Kedua, kewajiban untuk memberikan kompensasi terhadap tanah masyarakat adat yang diambil alih.

Syarat yang lebih tegas atas kepemilikan tanah masyarakat adat juga disebutkan dalam Pasal 16 Konvensi ILO 169, bahwa:

(1) Dengan tunduk pada pada ayatayat Pasal ini berikutnya, para penduduk yang bersangkutan tidak boleh dipindahkan dari tanah-tanah yang mereka tempati.

(2) Apabila penempatan kembali para penduduk ini dianggap perlu sebagai upaya pengecualian, penempatan kembali tersebut harus berlangsung hanya dengan persetujuan mereka yang bebas dan diberitahukan. Apabila persetujuan mereka tidak dapat 
diperoleh, penempatan kembali tersebut harus berlangsung hanya dengan mengikurti prosedurprosedur yang tepat yang dibuat oleh undang-undang dan peraturan-peraturan nasional, termasuk penyelidikan umum apabila tepat, yang memberikan kesempatan untuk mengajukan protes yang efektif dari para penduduk yang bersangkutan.

(3) Setiap waktu mungkin, para penduduk ini berhak kembali ketanah tradisional mereka, segera setelah alasan-alasan untuk penempatan kembali mereka dihentikan.

(4) Apabila penempatan kembali lagi tersebut tidak mungkin, dilakukan karena ditetapkan dengan persetujuan atau dengan tiadanya persetujuan tersebut melalui prosedur-prosedur yang tepat, maka para penduduk ini harus disediakan, dalam semua kasus yang mungkin dengan tanah-tanah yang kualitas dan status hukumnya stidak-tidaknya sama dengan tanah-tanah yang sebelumnya ditempati mereka, yang cocok untuk menyediakan kebutuhan-kebutuhan mereka yang sekarang, dan pembangunan mereka dikemudian hari. Apabila para penduduk yang bersangkutan menyatakan suatu pilahan untuk memberikan kompensasi dalam bentuk uang atau barang, mereka harus diberi berdasarkan jaminan-jaminan yang tepat.

(5) Orang-orang yang jadi ditempatkan kembali harus diberi kompensasi secara penuh atas kehilangan atau kerugian apapun yang diakibatkan.

Jika disimak ketentuan di atas baik UNDRIP maupun Konvensi
ILO 169, keduanya memberikan dasar pemikiran sekaligus dasar pengaturan atas kepemilikan tanah masyarakat adat. Tampak beberapa hal yang menjadi syarat pemindahan masyarakat adat dari tanah mereka. Hal tersebut hanya dimungkinkan sebagai tindakan pengecualian dan hanya dilaksanakan setelah memperoleh free and informed consent dari masyarakat adat yang bersangkutan, Jika ini tidak diperoleh, maka prosedur yang sesuai harus diadakan, termasuk hak untuk kembali lagi ketanah mereka, setelah dasar atau alasan relokasi mereka tidak berlaku lagi. Jika hal tersebut tidak dimungkinkan, tanah yang senilai atau kompensasi yang seimbang haruslah diberikan. Mencermati ketentuan ini, pada prinsipnya pasal tersebut menempatkan konsep free and prior informed consent sebagai prinsip utama yang mendasari ketentuan tersebut.

Ketentuan di atas sejalan dengan apa yang ditegaskan oleh Subhi Mahammassani ${ }^{12}$ sebagaimana dikatakan, dihampir setiap negara terdapat hukum yang membatasi hak milik dengan hal-hal yang menyangkut kepentingan umum. Atas dasar itu, jika negara atau pemerintah ingin mengambil alih suatu tanah atau sebagiannya, maka diisyaratkan adanya suatu alasan kepentingan umum, akan tetapi dalam hal ini di isyaratkan pula agar supaya negara harus terlebih dahulu memberi ganti rugi terhadap pemiliknya. Hal ini merupakan

12 Lihat selengkapnya dalam Subhi Mahammassani, Konsep Dasar Hak Asasi Manusia: Studi Perbandingan Syariat Islam dan Perundang-Undangan Modern, Tintamas Indonesia, Jakarta, 1993, hlm. 175-176 
konsekuensi logis terhadap pelepasan hak kepemilikan.

Berdasar pada ketentuan di atas, dapat disimpulkan bahwa pengambilan tanah masyarakat adat hanya dimungkinkan dengan alasan untuk kepentingan umum, dan setelah ada free and prior informed consent dari masyarakat adat setempat, serta kewajiban memberikan kompensasi yang adil. Dengan kata lain, pengambilan tanah masyarakat adat untuk kepentingan umum dimungkinkan tetapi harus dilaksanakan melalui due process of law. Dengan demikian dapat dijelaskan bahwa kepemilikan masyarakat adat atas tanah yang termuat dalam ketentuan tersebut tidak bersifat mutlak atau dapat dibatasi.

Ternyata hak masyarakat adat atas tanah dapat dibatasi. Dalam hal pembatasan ditinjau dari sudut HAM, Rukmana Amanwinata ${ }^{13}$ memandang sebagai sesuatu yang tampak ironis. Menurut beliau, HAM yang merupakan hak kodrati dan melekat pada jati diri manusia serta sebagai karunia Tuhan yang Maha Esa itu mustahil dibatasi oleh siapapun. Namun pada kenyataannya tidaklah demikian, mengingat sifat alami HAM, maka hak itu saling membatasi. Demikian pula hak negara dibatasi oleh hak individu dan sebaliknya.

Sebagaimana pemahaman di atas, bahwa konsekuensi pembatasan hak warga oleh hukum harus melibatkan partisipasi seluruh individu. Secara normatif ini merupakan hal yang sejalan dengan

\footnotetext{
${ }^{13}$ Rukamana Amanwinata, Pengaturan dan Batas Implementasi Kemerdekaan Berserikat dan Berkumpul dalam Pasal 28 UUD 1945, (Disertasi), Universitas Padjadjaran, Bandung, 1996, hlm. 271-272.
}

jiwa Konvensi ILO 169 sebagaimana telah dijelaskan sebelumnya bahwa konvensi ini menempatkan prinsip free end prior informed consent sebagai salah satu prinsip yang menjiwai pasal-pasalnya. Berdasar pada prinsip ini, partisipasi masyarakat adat sebagai salah satu muatannya. Konvensi ILO $169^{14}$ sebagaimana disebutkan dalam Pasal 6 ayat (1) [a] bahwa:

"Dalam memberlakukan ketentuan-ketentuan dalam Konvensi ini, para pemerintah akan: a) berkonsultasi dengan para penduduk yang bersangkutan, melalui prosedur prosedur yang tepat dan terutama melalui lembaga perwakilan mereka, setiap waktu pertimbangan sedang diberikan pada tindakan-tindakan legislatif atau administratif yang mungkin secara langsung mempengaruhi mereka)".

Ketentuan di atas pada prinsipnya mengharuskan kepada pemerintah untuk melibatkan partisipasi masyarakat adat dengan melalui mekanisme musyawarah atau berkonsultasi melalui prosedur yang benar dan melalui lembaga perwakilan mereka, manakala program-program legislatif dan administratif yang diperkirakan membawa dampak masyarakat yang sedang dibahas atau dipertimbangkan. Selain untuk halhal tersebut, partisipasi masyarakat adat melalui mekanisme konsultasi atau persetujuan, juga diatur dalam berbagai pasal. Di antaranya adalah Pasal 15 berkenaan dengan hak-hak SDA, Pasal 16 berkenaan dengan relokasi, Pasal 22 berkenaan dengan pelatihan kejuruan, dan Pasal 23

\footnotetext{
14 Hak-hak masyarakat adat untuk berpartisipasi juga disebutkan dalam beberapa pasal lainnya dalam Konvensi ILO 169, yaitu Pasal 2 (1), 5 , 7 dan 15.
} 
berkenaan dengan nafkah dan aktivitas ekonomi tradisional masyarakat adat. ${ }^{15}$

Deklarasi Rio tentang lingkungan dan pembangunan yang tidak mengikat secara hukum, juga menekankan pada hak untuk berpartisipasi bagi setiap warga negara, dan menyediakan prinsip khusus berkenaan dengan hak untuk berpartisipasi bagi masyarakat adat. Dalam Prinsip 22 Deklarasi Rio yang menyebutkan bahwa: "negara seyogyanya mengakui dan mendukung sebagaimana mestinya, identitas, budaya dan hak-hak masyarakat adat dan mengizinkan partisipasi aktif mereka dalam pencapaian pembangunan yang bersifat mendasar".

Hasil lain dari Konferensi Rio, seperti Agenda 21 dan PrinsipPrinsip Kehutanan (Forest Principles) juga mengakui hak masyarakat adat untuk berpartisipasi dalam hal-hal yang diatur dalam dua instrumen tersebut. Prinsip-Prinsip kehutanan misalnya, mendesak pemerintah untuk memajukan dan menyediakan kesempatan bagi partisipasi komunitas lokal dan masyarakat adat dan kelompok lainnya, dalam pembangunan,

15 Instrumen internasional lainnya juga melindungi hak untuk berpartisipasi. Dalam UDHR melindungi hak untuk berpartisipasi dalam Pasal 21 berkenaan hak untuk berpartisipasi dalam urusan politik bangsa, dan Pasal 27 berkenaan dengan hak untuk berpartisispasi dalam kehidupan budaya dimasyarakat. Hak berpartisipasi dalam ICCPR diatur dalam Pasal 25 berkenaan dengan hak untuk mengambil bagian dalam pelaksanaan urusan publik, dalam pemilihan umum, dan untuk memiliki akses terhadap layanan publik. Dalam ICESCR diatur dalam Pasal 15 berkenaan dengan hak untuk menmgambil bagian dalam kehidupan budaya dan menikmati keuntungan atau manfaat dari produk budaya. implementasi dan perencanaan kebijakan kehutanan nasional.

\subsection{Free and Prior Informed Consent sebagai Konsep Kebijakan Pengaturan yang Tepat terhadap Perlindungan Hak Masyarakat Adat.}

Uraian mengenai konsep Free end Prior Informed Consent (FPIC) telah dikemukakan pada bahasan sebelumnya dan hanya bermaksud menjelaskan bahwa konsep yang dikemukakan sangat relevan untuk diterapkan dalam permasalahan yang dibahas dalam tulisan ini, yaitu berkaitan dengan pencarian konsep pengaturan yang tepat terhadap perlindungan hak masyarakat adat atas tanah.

Pada awalnya konsep FPIC digunakan untuk melindungi kepentingan pasien di rumah sakit yang semestinya harus mengetahui setiap proses dan jenis pengobatan yang akan dilaluinya secara pribadi. Salah satu kodifikasi formal terhadap Prior Informed Consent (PIC) adalah Code of Nurenburg tahun 1947 yang berhubungan dengan syarat melakukan riset dan eksperimen medis terhadap manusia. Disinilah konsep PIC yang kemudian berkembang menjadi FPIC ditularkan kepada berbagai kegiatan non medis. FPIC sebagai kalusula medical normative yang awalnya bersifat individual, saat ini telah ditransformasikan dalam berbagai kaidah hukum internasional yang bersifat komunal. $^{16}$

\footnotetext{
16 Agus Surono, "Free And Prior Consent dalam Konflik Pengelolaan Sumber Daya Hutan", Jurnal Hukum Ekonomi dan Tekhnologi Fakultas Hukum Universitas Alazhar Indonesia, No. 1 Maret 2006, hlm 43
} 
Salah satu bentuk perkembangan konsep FPIC melalui hukum HAM internasional yang bersifat komunal adalah pengaturan perlindungan hak-hak masyarakat adat. Sebagaimana telah dijelaskan sebelumnya bahwa hukum HAM internasional menempatkan konsep FPIC sebagai salah satu prinsip dasar yang menjiwai isi pasal-pasalnya dalam menentukan kebijakankebijakan yang berhubungan dengan perlindungan hak-hak masyarakat adat.

Untuk lebih memahami secara mendalam pokok-pokok gagasan dari prinsip FPIC, khususnya perannya dalam mengkaji perlindungan hak masyarakat adat atas tanah maka terlebih dahulu akan dipaparkan pengertiannya, karena dengan memahami pengertiannya akan membantu untuk mengerti maksud dan gagasannya.

Sebuah definisi tentang PIC sebagaimana dikutip oleh Agus Surono ${ }^{17}$ :

"PIC adalah ijin sosial untuk bertindak, PIC merupakan cara ampuh untuk meyakinkan bahwa orang yang potensial terkena dampak memiliki semua informasi yang diperlukan sehingga dapat melakukan negosiasi dalam hubungan yang setara dengan penganjur proyek. PIC berarti bahwa orang yang terkena dampak memiliki kekuatan untuk memfeto proyek apapun yang terdapat dalam wilayah mereka. dengan kekuatan veto inilah hadir kekuatan penyeimbang untuk bernegosiasi dalam hubungan yang setara dengan penganjur proyek".

Selanjutnya Agus Surono menyebutkan empat unsur penting yang termuat dalam konsep FPIC

\footnotetext{
${ }^{17}$ Ibid., hlm. 44.
}

yang berlaku secara komulatif (bersama-sama). Secara definitif keempat hal tersebut diartikan sebagai berikut:

a) Free berkaitan dengan keadaan bebas tanpa paksaan. Artinya kesepakatan hanya mungkin dilakukan di atas berbagai pilihan bebas masyarakat.

b) Prior artinya sebelum proyek atau kegiatan tertentu diijinkan pemerintah terlebih dahulu harus mendapat ijin masyarakat.

c) Informed artinya informasi yang terbuka dan seluas-luasnya mengenai proyek yang akan dijalankan baik sebab maupun akibatnya

d) Consent artinya persetujuan diberikan oleh masyarakat sendiri". 18

Dari definisi PIC maupun keempat unsur yang terkandung dalam FPIC yang dikembangkan oleh Surono di atas menarik untuk dicermati. Dalam konteks perlindungan hak masyarakat adat atas tanah, terkait dengan pengelolaan SDA di wilayah masyarakat adat, konsep ini memberi jaminan bahwa masyarakat adat yang terkena dampak dari proyek pegelolaan SDA tersebut harus terlebih dahulu dimintai persetujuannya tanpa paksaan sebelum ijin kegiatan diberikan oleh pihak pemerintah. Negoisasi untuk mendapatkan persetujuan itu harus didahului dengan pemberian informasi yang jelas yang menyingkap keuntungan dan kerugian serta konsekuensi hukum atas pengelolaan SDA di wilayah masyarakat adat.

Konsep FPIC sebagaimana dijelaskan di atas, secara yuridis

\footnotetext{
${ }^{18}$ Ibid.
} 
termuat dalam Konvensi ILO 169 Pasal 6 ayat (2) dan Pasal 16 ayat (2). Terkait hak untuk memberikan persetujuan (right to consent) konvensi melindungi hak untuk memberikan persetujuan dari masyarakat adat ketika dalam upaya untuk menerapkan konvensi, pemerintah mempertimbangkan atau merencanakan program-program di bidang hukum atau administratif yang mungkin berdampak pada kehidupan mereka secara langsung. Sebelum memperoleh persetujuan (consent) dari masyarakat adat harus ada konsultasi atau musyawarah yang dilakukan yang didasari pada itikad baik dan dalam bentuk yang sesuai dengan keadaan masyarakat adat. $^{19}$ Prinsip FPIC juga diatur dalam Konvensi ILO 169 dimana ketika pemerintah mempertimbangkan relokasi masyarakat jika diperlukan sebagai tindakan yang luar biasa dan hanya setelah memperoleh free and informed consent dari masyarakat adat yang bersangkutan. ${ }^{20}$ Sebagaimana jelas dari rumusannya, persetujuan harus di dasarkan pada keputusan yang bebas dan sadar. Artinya ketika masyarakat adat mengambil keputusan mereka harus bebas dari paksaan, teror, penipuan dan bahwa mereka telah diberikan informasi yang jelas sebelum mereka memberikan persetujuan.

Berbagai gagasan telah dikemukakan oleh para ahli untuk mencari bentuk pengaturan terkait perlindungan hak masyarakat adat atas tanah. Gagasan yang berkembang saat ini adalah keiginan untuk membatasi hak menguasai negara yang bersumber dari Pasal 33 ayat 3 UUD 1945 sebagai landasan

\footnotetext{
${ }^{19}$ Pasal 6 ayat (2) Konvensi ILO 169.

${ }^{20}$ Pasal 16 ayat ayat (2) Konvensi ILO 169.
}

hukum bagi negara dalam pemanfaatan tanah dan pengelolaan SDA di Indonesia.

Dalam banyak kajian yang dilakukan oleh Lembaga Swadaya Masyarakat (LSM), seperti konsorsium Pembaruan Agraria (KPA) Bandung antara lain dinyatakan, telah terjadi kesesatan berfikir dikalangan Sarjana Hukum sebagai communis opinion doctorum yang sesungguhnya berakar pada tafsir atas pasal yang mengatur tentang hak menguasai negara atas bumi, air dan kekayaan alam yang terkandung di dalamnya yang mengacu pada Pasal 33 ayat (3) UUD $1945 .^{21}$

Salah satu sumber pelanggaran hak-hak masyarakat adat yang berakar dari makna Pasal 33 ayat 3 UUD 1945, sebagaimana diungkap oleh Saafroedin Bahar, ${ }^{22}$ yaitu asumsi yang dianut oleh jajaran Badan Pertanahan Nasional (BPN), bahwa dengan berdirinya Republik Indonesia, maka seluruh hak ulayat masyarakat adat dengan sendirinya beralih kepada negara dan menjadi apa yang disebut hak ulayat negara. Menurut beliau, secara in concreto doktrin ini merupakan pencabutan hak (onteigening), yang pada gilirannya dalam banyak hal pemerintah tidak berusaha memperoleh persetujuan masyarakat adat sesuai dengan asas free and informed consent.

Dalam hal yang sama,
Rakhmad syafa'at mengungkap

${ }^{21}$ Maria Rita Ruwiastuti, Sesat Pikir Politik Hukum Agraria..., Op.cit., hlm. 129-149.

${ }^{22}$ Saafroedin Bahar, Harmonisasi Hukum: Tantangan Terbesar dalam Perlindungan dan Pemajuan Hak Masyarakat Hukum Adat Dewasa Ini, dalam Rakmat syafa'at, et.al, Negara, Masyarakat adat dan Kearifan Lokal, Trans Publishing, Malang, 2008, hlm. 286. 
praktek penyelenggaraan negara secara sadar telah memanipulasi makna hakiki dari konsep penguasaan dan pemanfaatan SDA seperti yang dimaksud UUD 1945, setidaknya terdapat beberapa hal:

1. Pemerintah telah memberikan interpretasi sempit dan tunggal atas terminology negara (state). Negara semata-mata diinterpretasikan sebagai pemerintah saja bukan pemerintah (government) dan rakyat (people) sebagaimana dimaksud dalam tereminology negara dalam UUD 1945. Pengertian negara mempunyai empat komponen pokok, yaitu: wilayah (teritory), rakyat (people), pemerintah (government) serta kedaulatan (souvereignity). Karena itu, hubungan antara pemerintah dengan rakyat dalam konteks pemerintahan negara berada posisi yang sama, bukan dalam hubungan yang bersifat super subordinasi atau hubungan yang bercorak atasan (superior) dan bawahan (inferior).

2. Implikasi dari manipulasi interpretasi negara seperti ini adalah diciptakannya relasi yang bercorak super-subordinasi antara pemerintah dengan rakyat, dimana rakyat diposisikan sebagai subordinasi yang bersifat bawahan (inferior) sedangkan pemerintah berada pada posisi superordinasi yang memilki peran sebagai atasan (superior)

Pengejawantahan dari pola hubungan super-subordinasi antara pemerintah dengan rakyat seperti dimaksud tercermin dari pilihan paradigma pembangunan yang didominasi pemerintah (government dominated development), bukan pembangunan yang berbasis negara (state based development) maupun pembangunan yang berbasis pada masyarakat (community based development). Untuk mendukung pembangunan dan paradigma tersebut, pemerintah menciptakan instrumen hukum yang bermakna hukum pemerintah (government law) atau lebih dikenal dengan hukum birokrasi (bureaucratic law). ${ }^{23}$

Kecendrungan interpretsi di atas, menyebabkan munculnya hukum yang bersifat represif yang mengekspresikan kekuasaan pemerintah kemudian mangabaikan dan menggusur keberadaan sistem yang lain yang hidup dalam masyarakat. Salah satu ciri model hukum yang bersifat represif adalah hak-hak masyarakat adat dirumuskan secara mendua (ambiguity), disatu sisi diakui keberadaannya, tetapi disisi yang lain dibatasi secara mutlak dan bahkan secara eksplisit diabaikan keberadaannya. ${ }^{24}$ Mencermati kondisi ini, Muh. Mahfud MD mengungkapkan bagaimana pemerintah melanggar prinsip konstitusionalisme dan HAM, selengkapnya dalam pidato beliau dikatakan:

"Kenyataan bahwa tindakantindakan pemerintah yang melanggar prinsip konstitusionalisme, terutama melanggar HAM, selalu dibenarkan secara formal konstitusional karena diberi baju hukum berupa UU atau peraturan perundang-undangan lainnya telah menyebabkan pergeseran prinsip dan konsepsi dari negara hukum menjadi negara undang-undang. Inilah yang banyak terjadi di Indonesia, yakni berubahnya negara hukum menjadi negara undang-undang yang dibuat

\footnotetext{
${ }^{23}$ Rakmad Syafa'at, Op.Cit. hlm. 31.

${ }^{24}$ Ibid., hlm. 32.
} 
oleh pemerintah sebagai ukuran kebenaran...". 25

Pengamatan Mahfud MD di atas sangat tepat dalam mencermati keberadaan hukum di Indonesia saat ini, terutama berkenaan dengan konsep penguasaan dan pemenfaatan SDA yang bersumber dari Pasal 33 ayat 3 UUD 1945. Dalam rangka melindungi kepentingan penguasa (pemerintah), maka setiap tindakan pemerintah yang tidak adil selalu diberi pembenaran dengan pembuatan UU. Dalam hal ini Mahfud MD kembali mengatakan bahwa:

"ukuran-ukuran kebenaran bagi pemerintah bukan lagi rasa keadilan dan kepatutan dengan sukma etika yang tinggi melainkan kalimatkalimat undang-undang yang pembuatannya dilakukan melalui rekayasa bagi kepentingan pemerintah. Di dalam negara undang-undang yang seperti ini setiap tindakan pemerintah diberi pembenaran dengan pembuatan UU melalui penggunaan atribusi kewenanangan sehingga hukum ditempatkan sebagai alat justifikasi dengan watak positivistikinstrumentalistik. Hukum yang berwatak positivistik-instrumentalistik adalah hukum yang dijadikan instrumen untuk membenarkan apa yang akan atau telah dilakukan oleh penguasa". 26

Mempelajari kenyataan di atas, dari kalangan para ahli hukum muncul gagasan untuk membatasi wewenang negara yang bersumber pada hak menguasai atas tanah.

\footnotetext{
${ }^{25}$ Muh. Mahfud MD, Politik Hukum Hak Azasi Manusia, dalam Abdul Ghofur Anshori dan Sobirin Malian (ed.), Membangun Hukum Indonesia, Kreasi Total Media, Yogyakarta, 2008, hlm. 269.

${ }^{26}$ Ibid.
}

Maria Sri wulani Sumardjono menghendaki agar kewenangan negara yang bersumber dari hak menguasai negara atas tanah dibatasi oleh dua hal:

1. "Pembatasan oleh UUD. Pada prinsipnya, hal-hal yang diatur oleh negara tidak boleh berakibat terhadap pelanggaran hak-hak dasar manusia yang dijamin oleh UUD. Misalnya, suatu peraturan tidak boleh bias terhadap kepentingan suatu pihak, terlebih jika hal tersebut menimbulkan kerugian pada pihak lain. Bahwa apabila karena suatu hal seseorang harus melepaskan hak atas tanahnya, maka ia berhak memperoleh perlindungan hukum dan penghargaan yang adil atas pengorbanannya itu. Prinsip pengakuan terhadap hak orang lain itu harus dirumuskan secara tegas dalam peraturan perundang-undangan.

2. Pembatasan yang bersifat substantif. Dalam kaitan ini pertanyaan yang harus dijawab adalah, apakah peraturan yang dibuat itu relevan dengan tujuannya. Sesuai dengan Pasal 2 ayat (3) UUPA, maka semua perturan pertanahan harus ditujukan untuk terwujudnya sebesar-besar kemakmuran rakyat, sedang ruang lingkup pengaturan pertanahan dibatasi oleh Pasal 2 ayat (2) UUPA... . Filsafat Indonesia tentang konsep hubungan antara manusia dengan tanah menempatkan individu dan masyarakat sebagai kesatuan yang tidak yang tidak dapat terpisahkan atau menurut istilah Notonegoro kedwitunggalan. Pemenuhan kebutuhan seseorang terhadap tanah diletakkan dalam kerangka kebutuhan seluruh 
$\begin{array}{llr}\text { masyarakat } & \text { sehingga } \\ \text { hubungannya } & \text { tidak } & \text { bersifat } \\ \text { individualistis } & \text { semata, tetapi }\end{array}$

lebih bersifat kolektif dengan tetap memberi tempat dan penghormatan terhadap hak perseorangan. Dalam kerangka berpikir ini, hak-hak perseorangan atas tanah tidak bersifat mutlak, tetapi selalu ada batasnya yakni, kepentingan orang lain, masyarakat atau negara. Konsep hubungan ini diterjemahkan dalam Pasal 6 UUPA yang menyebutkan bahwa, semua hak atas tanah mempunyai fungsi sosial".

Dari uaraian di atas, tampak adanya kehendak pembatasan kekuasaan negara tidak boleh melanggar tujuan hak menguasai negara sebagaimana diatur dalam Pasal 2 ayat (3) UUPA yaitu, semua aturan perundang-undangan pertanahan harus ditujukan untuk sebesar-besar kemakmuran rakyat dengan tidak mengesampingkan hakhak masyarakat umumnya dan hak masyarakat adat khususnya. Ini merupakan bentuk perwujudan dari falsafah negara Indonesia yang menempatkan hubungan masyarakat dan negara sebagai satu kesatuan yang tidak bisa dipisahkan.

Dari kalangan birokrasi sendiri, juga timbul gagasan untuk mengurangi kekuasaan negara yang bersumber pada hak menguasai tanah oleh negara dengan alasan karena selama ini menempatkan negara sebagai pemegang kekuasaan atas tanah, dilain pihak rakyat amat lemah dalam pemilikan tanah. Persoalan yang terkandung dalam alasan ini adalah, kekuasaan negara yang berdasar pada hak menguasai tanah oleh negara sangat besar, sehingga konsep hak menguasai tanah oleh negara yang termuat dalam UUPA perlu diubah demikian Hasan Basri Durin ${ }^{27}$ (Menteri Negara Agraria/Kepala Badan Pertanah Nasional pada masa Kabinet Reformasi) menyampaikannya.

Secara normatif hak menguasai tanah oleh negara memberikan wewenang kepada negara mengatur dan menyelenggarakan peruntukan, penggunaan, persediaan, dan pemeliharaan bumi, air dan ruang angkasa tersebut; menetukan dan mengatur hubungan-hubungan hukum antara orang-orang dengan bumi, air dan ruang angkasa; menentukan dan mengatur hubungan-hubungan hukum orangorang dan perbuatan hukum yang mengenai bumi, air dan ruang angkasa. $^{28}$

Menurut Pasal 2 ayat (2) UUPA, hak menguasai negara hanya memberi wewenang kepada negara untuk mengatur (wewenang regulasi) ketiga hal tersebut di atas. Salah satu wewenang negara tersebut menurut Mohammad Bakri adalah wewenang untuk menentukan dan mengatur hubungan-hubungan hukum antara orang-orang dengan tanah. Selanjutnya dikatakan oleh Bakri, bahwa wewenang negara untuk mengatur hubungan hukum antara orang-orang termasuk masyarakat adat dengan tanah terkait erat dengan hubungan hukum antara negara dengan tanah, oleh karena hubungan antara negara dengan tanah sangat mempengaruhi dan menentukan isi peraturan perundang-undangan yang mengatur hubungan hukum antara masyarakat adat dengan tanah

\footnotetext{
${ }^{27}$ Dalam Muhammad Bakri, Hak Menguasai Tanah Oleh Negara: Paradigma Baru untuk Reformasi Agraria, Citra Media, Yogyakarta, 2007, hlm. 9.

${ }^{28}$ Pasal 2 ayat (1) UUPA.
} 
ulayatnya, serta pengakuan dan perlindungan hak-hak yang timbul dari hubungan-hubungan hukum tersebut. Hukum yang mengatur pengakuan dan perlindungan tersebut sangat diperlukan untuk memberi jaminan kepastian hukum kepada masyarakat agar hak-hak atas tanahnya tidak dilanggar oleh siapapun. Dengan demikian, sangat tidak tepat jika melihat hubungan negara dengan tanah terlepas dengan hubungan antara masyarakat adat dengan tanah ulayatnya dan hubungan antara perorangan dengan tanahnya. Ketiga hubungan ini menurut Muhammad Bakri merupakan satu kesatuan yang tidak dapat dipisahkan satu dengan yang lain, dan merupakan hubungan yang bersifat tritunggal. ${ }^{29}$

Wewenang negara yang bersumber pada hak menguasai tanah oleh negara sebagaimana dijelaskan di atas adalah memberikan suatu hak atas tanah (misalnya Hak Guna Usaha), atau hak-hak lainnya (misalnya HPH) dan mengatur pengambilan kekayaan alam yang terkandung dalam bumi, air dan ruang angkasa. ${ }^{30}$ Namun demikian, menurut Mohammad Bakri $^{31}$ penggunaan wewenang negara ini, dibatasi oleh hak-hak masyarakat adat yang bersumber pada hak ulayat. $^{32}$ Artinya, negara tidak bisa memberikan suatu hak atas tanah atau hak-hak lainnya kepada subjek hukum, atau mengambil SDA yang ada di wilayah masyarakat adat, tanpa persetujuan ${ }^{33}$ terlebih dahulu

\footnotetext{
${ }^{29}$ Mohammad Bakri, Op.cit., hlm. vi.

${ }^{30}$ Pasal 8 UUPA.

${ }^{31}$ Mohammad Bakri, Op.cit., hlm. 201.

${ }^{32}$ Supra note 215

${ }^{33}$ Menurut Mohammad Bakri, apabila tidak dicapai persetujuan (kata sepakat) antara masyarakat adat setempat dengan investor yang diberi hak untuk melakukan eksploitasi
}

dari masyarakat adat setempat. Secara tidak langsung pembatasan wewenang negara juga tersirat dalam ungkapan Baramuli sebagaimana disebutkan bahwa hanya anggota masyarakat adat yang boleh memakai tanah sedangkan orang lain tidak, kecuali mendapat izin dari kepala adatnya. Secara lengkap ungkapan beliau adalah:

"Menurut UUPA, hak ulayat itu ada ditangan masyarakat hukumnya. Hanya anggota masyarakat yang boleh memakai tanah, orang lain tidak boleh, kecuali ada izin dari kepala adatnya... . Dengan demikian jika pemerintah memberikan penggunaan dalam bentuk HGB, HGU atau HPH maka harus bermanfaat pada rakyat, berarti harus bermanfaat bagi masyarakat adat setempat". ${ }^{34}$

Dari kedua pendapat di atas, bermakna bahwa wewenang negara untuk memberikan suatu hak atas tanah (HGU, HGB atau HPH) harus mendapatkan izin atau persetujuan terlebih dahulu dari masyarakat adat setempat. Hal ini bermakna pula bahwa wewenang negara tersebut di batasi oleh hak ulayat masyarakat adat. Pembatasan wewenang

SDA, tentang bentuk dan besarnya bagian hasil eksploitasi SDA yang diterima oleh masyarakat adat, maka dapat dilakukan pencabutan hak atas tanah sebagaimana diatur dalam UU No. 20 tahun 1961 tentang Pencabutan Hak Atas Tanah Dan Bendabenda Yang Ada di Atasnya. Namun demikian menurut Bakri bahwa pencabutan hak atas tanah merupakan upaya terakhir setelah terlebih dahulu diusahakan upaya lain melalui musyawarah untuk mencapai mufakat. Mohammad Bakri. Loc.Cit.

${ }^{34}$ Loekman Soetrisno, Hak-Hak Ekonomi: Antara Cita-cita dan Kenyataan, dalam Komisi Nasional Hak Asasi Manusia, Hak Asasi Manusia dalam Perspektif Budaya Indonesia, PT Gramedia Pustaka Utama, Jakarta, 1997, hlm, 170. 
negara sebagaimana dijelaskan di atas, sejalan dengan konsep FPIC di mana masyarakat adat diharuskan ikut berpartisipasi dalam memberikan persetujuan sebagai pihak yang menerima secara langsung dampak dari pembangunan SDA di wilayah mereka. Pola kebijakan semacam ini menjadi sangat penting dan bisa aplikatif dalam upaya perlindungan hak-hak masyarakat adat.

\section{Penutup}

1. Terdapat titik singgung antara pembatasan hak menguasai negara dengan konsep FPIC. Tujuan pembatasan hak menguasai negara atas tanah dan konsep FPIC pada prinsipnya menempatkan hubungan antara pemerintah dan rakyat pada kedudukan yang sama dan sederajat. Karena pada hakikatnya rakyatlah yang memiliki kedaulatan tertinggi dalam sebuah negara. Dengan demikian, ketika FPIC dilaksanakan dan diakomodir dalam produk hukum negara ditingkat nasional ataupun daerah mempunyai pengaruh pada berbagai hal, diantaranya adalah dengan memberikan persetujuan masyarakat adat dalam rangka mendukung upaya pembangunan menunjukkan bahwa tidak ada kekuasaan yang lebih tinggi selain dari suara rakyat itu sendiri. Selain itu persetujuan yang dihasilkan antara investor dan masyarakat adat merupakan pelaksanaan dari asas yang sangat mendasar dalam sebuah negara hukum yaitu asas equality before the law. Disamping itu, dengan mencapai persetujuan masyarakat adat atas proyek pengelolaan SDA melalui mekanisme FPIC dapat mencegah konflik dikemudian hari.

2. Kewajiban pemerintah dalam mengimplementasikan hukum HAM internasional harus disertai dengan komitmen untuk melakukan pemenuhan hak yang dijamin di dalam hukum HAM internasional. Dalam hal ini, diharapkan kepada pemerintah, baik pemerintah pusat maupun pemerintah daerah dalam menyusun kebijakan peraturan berkaitan dengan perlindungan hak masyarakat adat agar memasukkan konsep free and prior informed consent sebagaimana yang diamanatkan dalam ketentuan-ketentuan hukum HAM internasional.

\section{Daftar Pustaka}

Ahmad Kosasih, HAM dalam Perspektif Islam: Menyingkap Persamaan Antara Islam dan Barat, Salembah Diniyah, Jakarta, 2003.

Ibnu Elmi A.S. Pelu, et.al, Reaktualisasi Cita Hukum dalam Pembangunan, InTrans, Malang, 2007.

I Nyoman Nujaya, Pengelolaan Sumber Daya Alam dalam Perspektif Antropologi Hukum, Prestasi Pustaka Publisher, Jakarta, 2008.

Loekman Soetrisno, Hak-Hak Ekonomi: Antara Cita-cita dan Kenyataan, dalam Komisi Nasional Hak Asasi Manusia, Hak Asasi Manusia dalam Perspektif Budaya Indonesia, PT Gramedia 
Pustaka Utama, Jakarta, 1997.

Maria Rita Ruwiastuti, Sesat Pikir Politik Hukum Agraria, Penyunting Noer Fauzi, Insist Press, KPA dan Pustaka Pelajar, Yogyakarta, 2000.

Rafael Edi Bosko, Hak-Hak Masyarakat Adat dalam Konteks Pengelolaan Sumber Daya Alam, ELSAM, Jakarta, 2006.

Rakhmat Syafa'at, et.al, Negara, Masyarakat Adat dan Kearifan Lokal, Trans Publishing, Semarang, 2008.

Subhi Mahammassani, Konsep Dasar Hak Asasi Manusia: Studi Perbandingan Syariat Islam dan PerundangUndangan Modern, Tintamas Indonesia, Jakarta, 1993.

Agus Surono, "Free And Prior Consent dalam Konflik Pengelolaan Sumber Daya Hutan", Jurnal Hukum Ekonomi dan Tekhnologi Fakultas Hukum Universitas Alazhar Indonesia, No. 1 Maret 2006.

Fokky Fuad, "Hak Masyarakat Hukum Adat dalam Pengelolaan Sumberdaya Tambang di Indonesia", Jurnal Hukum Ekonomi dan Tekhnologi Fakultas Hukum Universitas Alazhar Indonesia", No. 1 Maret 2006.

Rukmana Amanwinata, Pengaturan dan Batas Implementasi kemerdekaan Berserikat dan Berkumpul dalam Pasal 28 UUD 1945, (Disertasi),
Universitas Padjajaran,
Bandung, 1996.

Sri Rahayu Oktoberina, "Hak Asasi

Manusia dan Lingkungan

Hidup dalam Hukum

Internasional", Jurnal

Keadilan, Vol. 2. No. 2, Tahun 2002.

Undang-Undang Dasar (UUD) 1945.

Undang-Undang Nomor 5 Tahun 1960 tentang Peraturan Dasar Pokok Agraria (UUPA).

Undang-Undang Nomor 41 Tahun 1999 tentang Kehutanan.

Universal Declaration Of Human Rights (UDHR), 1948.

International Covenant on Civil and Political Rights (ICCPR), 1966.

International Covenant on

Economic, Social, and

Cultural Rights (ICESCR) 1966.

International Convention on the Elimination of All form of Racial Discrimination (ICERD).

International Labour Organisation Convention No. 169 Concerning Indigenous and Tribal Peoples in Independent Countries, 1989.

Agenda 21, United Nations Confrence on Enviorenment and Development,1992.

Rio Declaration on Environment and Development, 1992.

United Nations Declaration on the Rights of Indigenous Peoples (UNDRIP), 2007. 